\title{
Formulating a Model of the Mexican Economy
}

\author{
by GILBERTO ESCOBEDO
}

\begin{abstract}
In this article Mr. Escobedo presents two alternative approaches to the development of an econometric model of the Mexican economy. One model is based on a neo-Keynesian framework of analysis; the other model incorporates the theoretical positions of monetarists. Before summarizing the structure of the two models, Mr. Escobedo expresses his views of the debate between monetarists and neo-Keynesians.
\end{abstract}

For some background information into the complexities of the Mexican economy, the reader may wish to refer to an article by Mr. Escobedo in the June issue of this ReviEw.

$\mathbf{O}_{\mathrm{N}}$ evolution of economic theory is that it closely follows the economic performance of the leading industrial countries of the Western World. In the present century we can trace this trend very clearly. When the world fell into the "great economic depression" in 1933, the prevailing theory assumed the problem away and therefore could not provide a solution for bringing the economy out of the difficulty. The Keynesian approach emerged at that time as the "great savior" of the economic discipline. Monetary variables were considered irrelevant and fiscal policy came to be regarded as the "solution" in a "new era" of Government intervention in the economy.

In the post-war period, as economies became more sophisticated and some neo-Keynesian solutions to economic policy were not proven to be as efficient as previously thought, monetary theory regained importance. ${ }^{1}$ Much discussion has occurred in the last 5 or 6 years regarding the relative importance of fiscal versus monetary policy. The question has not been settled definitely, although a consensus of opinion seems to be emerging. ${ }^{2}$ The present state of the discussion seems to lie at least in part in what can be considered the main exogenous policy variable - Govemment expenditures for Keynesian theory or money stock for the monetary theory - since each approach

\footnotetext{
1Miton Friedman, "The Role of Monetary Policy," American Economic Review (March 1968).

2Good examples of these discussions are Frank Deleenw and John Kalchbrenner, "Monetary and Fiscal Actions: A Test of Their Relative Importance in Economic Stabilization - Comment," this Review (April 1969), pp. 6-11, and Leonall C. Andersen and Jerry I. Jordan, "Monetary and Fiscal Actions: A Test of Their Relative Importance in Economic Stabilization - Reply," this Review (April 1969), pp. 12-16.
}

assigns an important role to the effectiveness of those variables in the system.

Furthermore, the discussion has been extended to the question of how much benefit or loss is added to the economic system when the policymakers use the instruments they have available to obtain a desired goal. Given that the results of these actions are subject to a high degree of uncertainty, the question raised is whether it is better for policymakers to use the imperfect instruments available or whether policy interference should be kept at a minimum with the system left to "self correct" as Milton Friedman suggests.

The criticism of the "activist" position rests on the prenise that serious limitations exist in the ability to predict both the behavior of the system in the absence of action and the effect of action. There is also a time consuming process involved in correcting the lags between the recognition of the problem, the formulation of appropriate action, the implementation of action, and the results of such action. Actions taken without knowledge of the adjustment process during these lags would tend to destabilize an inherently stable economy.

The main criticism of the "self-correcting" position is focused on the assumptions that the economy "tends" toward stability and that the use of an activist policy is only "disruptive." This assumption cannot be proven for no test could completely isolate the system from Government actions which are not aimed at stabilization. Neo-Keynesians therefore conclude that "... the evidence of both Keynesian and monetarist models of economic activity suggests that we 
live in an economy of persistence rather than selfcorrection" because the economy is permanently subject to multiplier effects and therefore intervention in the economy is called for as a corrective device. ${ }^{3}$

Whatever the outcome of this controversy might be, it is clear that there is a recognized influence on the economy from changes in both monetary and fiscal variables. The policymaker thus needs to follow an analytical framework in predicting the behavior of the economic system, so that the level of uncertainty of his actions can be minimized. We will disregard in this paper a discussion of self-correcting mechanisms which, even if relevant in countries like the United States, would not necessarily be applicable in more Government-oriented economies like Mexico.

\section{ECONOMIC POLICY IN DEVELOPED ECONOMIES}

\section{The Keynesian Approach}

The original version of the Keynesian theory emphasized the role of fiscal variables, such as Government expenditures and taxes, as the most important policy instruments for influencing economic activity. The effect of a fiscal action on spending is viewed as a multiple of the original magnitude of such fiscal action. Government spending, for example, is transformed into a direct demand for goods and services, which generates additional income, which in turn is spent. This process continues until the leakages (savings and taxes) bring it to an end - the final result being a multiple of the original Government expenditure. Taxes affect disposable income (a major determinant of consumer spending) and profits of businesses (a major determinant of investment spending). Therefore, according to Keynesians, budget surpluses or deficits are good measures of the influence of Government spending or taxing on economic activity.

More advanced neo-Keynesian interpretations recognize monetary actions as an indirect influence on economic activity through the effect of changes in market interest rates. But even in this case the way in which a budget deficit is to be financed has not always received adequate consideration.

With the help of the Hicksian IS-LM framework, the effects on the economy of fiscal actions, such as an increase in Government spending, can be traced. This increase induces a change in both consumption and saving, which in tum increases investment (an

3 See Arthur M. Okun, "Fiscal-Monetary Activism: Some Analytical Issues," Brookings Papers on Economic Activity (No. 1, $1972)$, p. 147 . upward movement along the IS schedule as well as a shift due to an accelerator type effect) and therefore income in the next period. But this shift of the IS curve will have an effect on the demand for money and, depending on what happens to its supply, market interest rates may or may not move up. If there is no displacement to the right of the LM curve, the final effect of increased Government expenditures will be a higher level of income, but also higher interest rates prevailing in the market.

For Keynesians the money stock in equilibrium is given exogenously, as is the price level. Adjustments from a low to a higher equilibrium position through developments in the monetary sector occur as a result of an outward shift in the LM curve. This shift, induced by a change in the money stock, reduces the rate of interest which, in turn, promotes investment and higher levels of income, consumption, and savings. The process continues until new equilibrium levels of income and interest rates are achieved.

This static framework has been developed into a dynamic system allowing prices and credit rationing effects to affect the slopes and positions of the pairs of IS-LM curves determined in each income period." Presently the Keynesian framework allows for changes in monetary and fiscal actions to take place at the same time, and considerations about the financing of Government expenditures can be introduced. Financing with monetary expansion will result in the full Keynesian multiplier effect while financing by either taxes or borrowing from the public has a smaller multiplier effect on spending. ${ }^{5}$

Neo-Keynesians also recognize that exogenous Govemment expenditures (whether directed towards the achievement of allocation, distribution or stabilization objectives) have to be integrated in such a way that an expenditure intended to achieve stabilization objectives does not hamper the desired distribution or allocation of resources. ${ }^{6}$ This is a difficult distinction to document empirically, especially in economies near full employment in which the trade-off between the goals of economic policy may be sharper. It is also difficult to classify the amounts and types of debt the

4J. R. Moroney and J. M. Mason, "The Dynamic Impacts of Autonomous Expenditures and the Monetary Base on Aggregate Income, Journal of Money, Credit and Banking (Noyember 1971), pp. 793-814.

5 James Tobin, "An Essay on the Principles of Debt Management" in Essays in Economics (Chicago: Markham Publishing Company, 1971).

6Richard Musgrave, The Theory of Public Finance (New York: MoGraw-Hill, 1959). 
Government uses to finance each type of expenditure. Consequently, the portfolio approach, as developed by James Tobin, attributes both a direct and an indirect effect on the economy to fiscal actions, depending on the relative amounts and terms of the debt. This development gives greater detail to the final impact of Government expenditures and brings the fiscal and monetary approaches closer together.

\section{The Monetarist Approach}

Outside the context of the Keynesian framework of IS-LM analysis, a group of economists in the United States have developed a theoretical approach that stresses the influence of monetary and financial variables on economic activity. This approach is a reformulation of the quantity theory which emphasizes the role of money as an asset. In this framework, the demand for money is treated as a part of capital or wealth theory, and the concern is with the composition of asset portfolios which provide utility or satisfaction to holders. ${ }^{7}$

Two well-defined markets are set forth. Economic entities make choices in the market for goods and services and in the market for financial assets, so a Walrasian framework of supply and demand is necessary for each financial asset. Market interest rates (prices of financial assets) and changes in the outstanding stocks of most financial assets are determined by the market process, along with prices and quantities of goods and services. ${ }^{8}$

The modem quantity theorists assume that the real money stock and the level of real income are determined by this supply and demand mechanism, which eventually will come to a high-employment equilibrium, since it is assumed that the economy has an "inherent force" towards stability. Therefore, changes in the nominal stock of money will not affect "real" variables in the long run, but will influence only nominal interest rates, prices, and spending on goods and services. ${ }^{9}$

This theory also incorporates the view that the influence of fiscal actions depends mainly on the method of financing Government spending. Financing

\footnotetext{
TMiton Friedman, "Money: Quantity Theory," Intemational Encyclopedia of the Social Sciences (vol. X, 1968), pp. 432-47.

8 Leonall C. Andersen and Jerry L. Jordan, "Monetary and Fiscal Actions: A Test of Their Relative Importance in Economic Stabilization," this Review (November 1968), pp, 11-24.

"Milton Friedman uses this argument in "The Role of Monetary Policy" to show how badly monetary policy has been conducted in the United States.
}

by either taxing or borrowing from the public involves a transfer of command over resources from the public to the Government, giving way to the "crowding out" effect on private expenditures. That is, the Government will use funds otherwise available to the private sector, therefore affecting the rate of interest and eventually total spending on goods and services.

Summing up, we could say that the modern quantity theory stresses the influence of money on the pace of economic activity. Such a relation has been empirically tested only in an aggregated level where the results are satisfactory, but the monetarists have made little effort to test the responses to financial variables in a disaggregated structural-type model."

\section{ECONOMIC POLICI IN DEVELOPING ECONOMIES}

The popular Keynesian theory developed in the industrialized countries during the $1940 \mathrm{~s}$ and the $1950 \mathrm{~s}$ was not direotly applicable to the underdeveloped economies. Special adjustments had to be made to consider problems such as industrialization, income distribution, and growth. There were the so called "developing theories" advanced by nationals of these countries like Raul Prebisch of Argentina, Juan Noyola of Mexico, Celso Furtado of Brazil, and Anibal Pinto of Chile, as well as by foreigners such as Nicholas Kaldor, Ragnor Nurske, Harry G. Johnson, and Walt Rostow. These "developing theories" followed two main courses.

\section{The Struchuralist Position}

This approach, which was promoted primarily by the United Nations, stresses that inflation is not a monetary phenomenon, but the result of disequilibria of a very real nature that are expressed in the form of the general level of prices. Inflation can be attributed to struotural factors (population and productivity), dynamic factors (different rates of sectoral growth), and institutional factors (behavior of public and private sectors) ${ }^{11}$

10Leonall C. Andersen and Keith M. Carlson, "A Monetarist Model for Economic Stabilization," this Review (April 1970), pp. 7-25. See also Gene Fisher and David Sheppard, "Effects of Monetary Policy on the United States Economy," Organisation for Economic Cooperation and Development, Occasional Studies (December 1972).

1Juan Noyola, "El Desarrollo Economico y la Inflacion en Mexico y otros Paises Latinoamericanos," Investigation Economica (1956). Also see United Nations Economic Commission for Latin America, Development Problems in Latin America (Anstin: University of Texas Press, 1971), pp. $161-211$. 
Once inflation starts, there is an inherent "propagation" in the economic system due to the state of income distribution and to the behavior of the private and public sectors. The conclusion of this group is that if a choice had to be made between inflation and economic stagnation or unemployment, inflation is preferable.

According to this approach, developing economies should direct their efforts towards the stimulation of growth by means of industrialization. This would be achieved by promoting import substitution so that, at the same time the terms of trade are improved, an increased capacity to import would make it possible to sustain the large capital needs of development. Therefore, Government expenditures should be heavily directed toward promoting the industrial infrastructure of the comtry. This process would allow productivity to increase and ameliorate the problem of income distribution.

An additional effort would have to be made by the Government in order to guarantee the productivity of private investment which sometimes is "poorly oriented, directed to superfluous goods or to foreign markets."12 However, at the beginning of the 1960s, when some of these countries were finishing their import substitution process, and the pace of industrialization was slowing, a new ingredient was incorporated into the problem of development. The patterns of commercial policy of the advanced countries had to be changed, so as to make it possible for those countries in the process of development to export non-traditional products which, under prevaling conditions, could not be placed competitively in the international markets.

\section{The "Orthodox" Position}

This approach was promoted mainly by the International Monetary Fund and other international agencies. It also has a heavy Keynesian influence, but gives more consideration to the financial sector and especially to the rate of exchange. The increase in prices is viewed as originating with the expansion of additional income, from the inherent process of development, from the expansion of bank and extra-bank credit, and from increasing costs due to "commercial practices."

\footnotetext{
t2For a more recent interpretation of the structuralist position, see David Ibarra "Mercado, Desarrollo y Politica Economica," El Perfl de Mexico en 1980, ed. Siglo XXI, 1970, and Luis DiMareo, ed. International Economics and Development, Essays in Honor of Raul Prebisch (New York: Academic Press, 1972), p. 11 .
}

Furthermore, this approach holds that external factors are basic in explaining monetary disequilibria. The reasoning is that Government spending, or a surplus in the current account of the balance of payments, produces an increase in aggregate demand, which induces increases in investment. In turn, increased growth of income is promoted and, consequently, imports grow at a higher rate than income. ${ }^{13}$ Since the growth of exports is slower, a deficit in the current account occurs. A change in relative prices - domestic and foreign - or a monetary policy oriented toward sustaining output growth at high rates, accentuates the balance-of-payments deficit and it becomes necessary to devalue in order to restore extemal equilibrium. ${ }^{14}$ Later developments of this approach rejected devaluation as a necessary means for restoring equilibrium, turning more to domestic and foreign savings for that purpose and, therefore, making development with price stability the goal of economic policy.

In general, one can conclude that the "developing theories" have relied very heavily on Keynesian theory. Even the most recent approaches to economic policy, with a heavy content of social considerations, are still based on a Keynesian-type mechanism. This is only natural if one considers that capital markets and financial institutions have been almost nonexistent in developing countries and that Govemment plays a central role in the economic mechanism.

To a great degree Mexico has been an exception to the usual experience of developing economies. In Mexico a wide and competing banking system has been developed which has attracted not only domestic but also considerable amounts of foreign savings. Nevertheless, economic policy is still conducted mainly in the Keynesian tradition, giving relatively little attention to the role of financial variables in the economic system. Therefore, the exploration of new approaches to economic policy seems appropriate.

Such is the purpose of this study, empirical results of which are summarized in the remainder of this paper. The analysis has been directed only to shortterm economic policy, but it seems necessary that similar considerations be given to long-term policy consistent with the goals of employment and more equitable income distribution.

\footnotetext{
${ }^{13}$ The income elasticity of imports is normally assumed to be greater than one.

14For a more detailed view of these approaches, see Leopoldo Solis, "Mexican Economic Policy in the Post-War Period: The Views of Mexican Economists," Supplement to American Economic Revietw (June 1971).
} 


\section{DEVELOPMENT OF THE MODELS}

The institutional characteristics and the historical background of Mexico, which were presented in the june 1973 issue of this Review, provide a foundation for the two econometric exercises presented below. From these two exercises we will try to determine if the recent theoretical and empirical developments in industrialized countries can be used in developing economies which are concemed more with growth and income distribution than with stabilization and full employment. In so doing, the traditional, but still pop" ular, approaches given by the "developing theories" will be disregarded.

The construction of the models could have been approached from two extremes. The models could have incorporated "a prioristic policies" based on theories rather than empirical research, or they could have been constructed around "empirical policies" based on experience with little theoretical background. ${ }^{15}$ Since neither of these extremes is desirable, two models have been developed of an intermediate type based on knowledge of past economic behavior. These models are appropriate for testing the relative importance of fiscal and monetary policies in income-expenditure determination. By statistical simulation we can determine which of the two approaches fits best.

The models only consider quantitative policy - that is, moderate changes in quantitative instruments such as Government expenditures and money supply. The short-run structure of the economic environment is assumed to remain unchanged. No consideration is given to policies of increasing complexity, such as changes in the monetary or fiscal structure, the pattern of income distribution, or the state of property arrangements.

It is hoped that the results of these efforts will be helpful for a number of purposes. First, they should provide a framework for evaluating the attainability and desirability of altemative policy objectives, given the maintenance of present relationships. In addition, the results should indicate whether a change in these relationships is necessary, and if so, how the alteration conld be accomplished.

A word of caution should be advanced regarding availability of data. Mexico, as is the case with most developing countries, suffers from a considerable lack of statistical data, and this situation has been de13an Tinbergen, On the Theory of Economic Poltcy (Amster-
dam: North Holland Publishing Company, 1955). teriorating rather than improving in recent years. The national accounts are only available from 1950 to 1968 , the last input-output table is for 1960, and no flowof-funds tables have yet been produced. Therefore, the construction of reliable statistical series for our purposes was a difficult task which excluded those variables undocumented. Nevertheless, awareness of the difficulty in gathering consistent and reliable information is one of the "side-benefits" of model building and should serve as a feed-back to those institu tions involved in statistical development.

\section{A Summary of the Fiscal Model Structure}

Consistent with the Keynesian approach, the main economic policy variable of this model is Government expenditures which are considered exogenous to the system. ${ }^{16}$ The other instrumental variable is the rate of interest, which the central bank regards as "controllable." The rate of interest acts as the credit rationing variable. ${ }^{17}$

The purpose of the model is to estimate the financing requirements of a given level of Government expenditures while trying to meet the goals of a high growth rate of gross domestic product, a stable rate of exchange, and a "minimum" of inflation.

The restrictions imposed on the model are the budget and balance-of-payments deficits. That is, if the growth of GDP is to be promoted with a "minimum" of price and exchange rate instability, Government expenditures will have to follow a "moderate" rate of growth. Failure to do this will necessarily affect both Government and balance-of-payments deficits, and domestic and foreign stability will not be possible. Therefore, the relevant endogenous variables responding to different policy shocks are in the following sequence: GDP, taxes, imports, international assets, domestic credit, and the money supply (see Exhibit I).

\footnotetext{
10In other words, in this first model we will test the hypothesis that Government expenditures are an independent variable which will have broad and rapid effects on ecomomic activity.

17This necessarily implies the existence of excess demand for funds at the "official" rates. The assumption of excess demand for funds implies that since the interest rate is fixed at an "official celling" there will be times when there are actually two interest rates: the offical and the marke rate. The latter one cannot be measured systematically and, therefore, the interest rates are not introduced in the credit equations. Offeial interest rates enter only in the bank's liabilities equations as a variable hepping to explan the total amount of funds received by the banking system in a given period.
} 


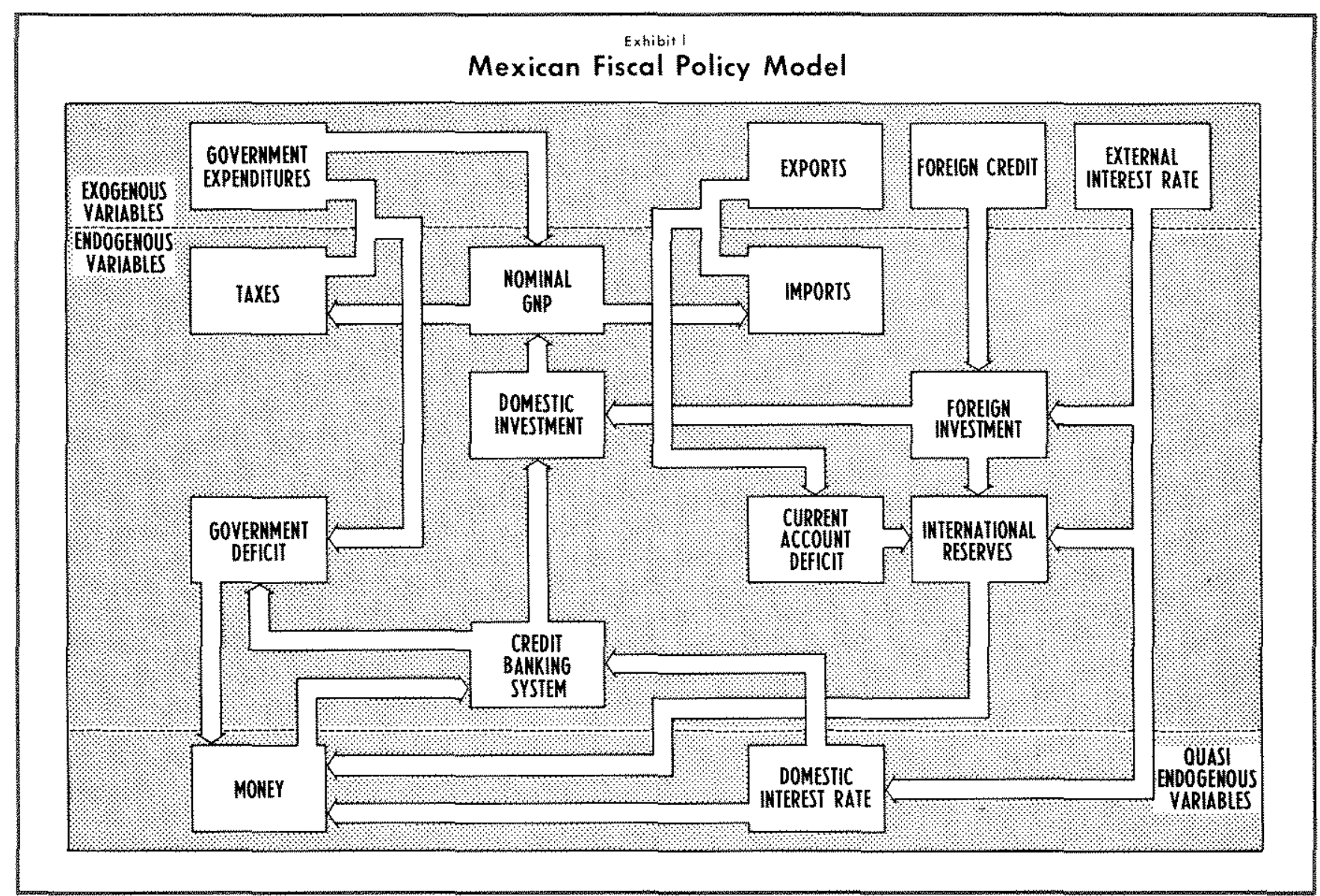

There is a basic channel which, by way of a multiplier, transforms private and public investment into expenditures on goods and services. Government investment is determined exogenously and private investment depends on the remaining funds available in the banking system after Government expenditures are financed. ${ }^{18}$ The total amount of credit available depends on the level of domestic saving and on the interest rates prevailing in domestic and foreign markets.

Government expenditures will be financed in the first instance by revente coming mainly from income and indirect taxes, which are endogenous to the system and a function of income and GDP. Four additional sources are considered for financing these expenditures: a) credit from the private banking system, b) credit from the central bank, which will be reflected in an increase of the money supply or in a reduction in the amount of credit discounted, c) foreign credit, and d) credit from the non-banking sector.

18 See Richard A. Musgrave, Theory of Public Finance, Chapter 25 and Roger W. Spencer and William $P$. Yohe, "The 'Crowding Out' of Private Expenditures by Fiscal Policy Actions," this Review (October 1970), pp. 12-24.
Private bank credit to the Government (including that of investment banks) depends on the legal reserve requirements which by law are kept in some form of Government debt instrument instead of deposits bearing no interest. This way of allocating public debt permits the central bank to rely less on an expansion in the stock of money and, therefore, helps avoid heavy pressures on inflation. Financing with new money was typical during the inflationary periods in Mexico.

Legal reserve requirements are a fixed proportion of demand deposits, time deposits, "bonos financieros" (a demand deposit bearing interest) and "hipotecarios," 1 " which in turn depend on GDP and the differential between domestic and international inter. est rates.

The amount of credit that the central bank grants to the Government (the level of Treasury bills purchased), in addition to that coming from domestic and

\footnotetext{
$10 \mathrm{~A}$ discussion of these terms is provided in the screened section of "The Response of the Mexican Economy to Policy Actions," this Review (June 1973), p. 21 .
} 
international sources, is also endogenously determined. In order to extend this credit, the central bank has to lower its discount rate to private banks, reduce its holdings of intemational assets, or in turn increase the money supply.

Changes in international reserves depend upon the results of the balance of payments, which is the difference between exogenously fixed exports minus endogenously determined imports of consumer goods, equipment, raw materials, and services. Imports are mainly a function of current and lagged real output and investment. If changes in international reserves are endogenous, part of the monetary base also becomes endogenous, and the central bank will have no other alternative to finance the Govemment's deficits but to reduce the amount of credit available to private banks. This action will be taken because of the inflationary risk involved in the creation of "new" money in excess of trend. Therefore, the whole process of "crowding out" takes place and private investment is reduced. ${ }^{20}$

The only way in which this process will not occur is if the private sector borrows from international money markets. This borrowing will take place only when the interest rate differential becomes significantly important so that the foreign interest rate plus the "risk" factors involved in foreign borrowing are lower than the domestic rate. The effect that such borrowing has on the change of international reserves depends on changes in imports, exports, and the amount of debt the Government decides to float in international markets.

Summing up, the four main endogenous variables in the system are private investment, imports, taxes, and credit. All are determined mainly by the behavior of GDP which, in tum, is heavily dependent on Government expenditures. The Keynesian multiplier will work fully if Government spending is financed with "new" money, but the ultimate impact will be decreased if any amount of funds is taken from the private sector. Also, the multiplier is inftuenced by the behavior of imports, since part of the increased de.

\footnotetext{
2oSee Franco Modigliani, "Long-Run Implications of Alternative Fiscal Policies and the Burden of National Debt, Economic Journal (December 1961), and Albert Burger, The Money Supply Process (Belmont, California: Wadsworth Publishing Company, Inc., 1971). The nonetary base in this case would have an additional term for international reserves so the definition of the base would be: Base $\left(B^{4}\right)=$ total bank reserves $(R)$ of international reserves private bank borrowing $(A)+$ currency $(\mathrm{CP}) ; \mathrm{B}^{\mathrm{a}}=$ $\mathrm{A}-\mathrm{A}+\mathrm{CP}+$ international reserves.
}

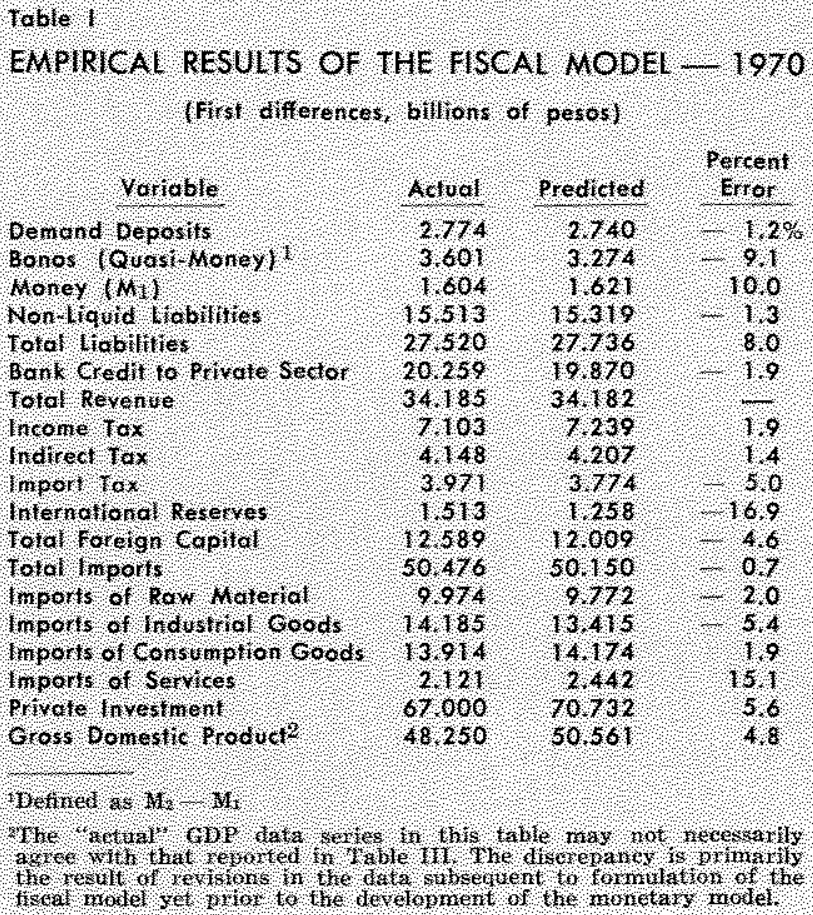

mand will be transferred to the extemal sector with no further multiplier effect on the domestic economy. ${ }^{21}$

\section{Empirical Results of the Fiscal Model}

This model offers a far more detalled breakdown than that mentioned above, but it was not considered relevant to the argument of this paper. There is a breakdown by type of imports, by taxes, and by the main assets and liabilities of the banking system. The user of the model might find these helpful in understanding the behavior of the aggregated variables, and they will also be useful if the model is used for policymaking purposes.

The estimation of the model was made with annual figures. Due to the considerable number of variables involved (41 endogenous and 63 exogenous), and the availability of data, it was not possible to estimate it using quarterly data, as was possible in the monetary model. Therefore, the simulation was done on an annual basis as was the 1973 forecast.

In Table I the 1970 simulation is compared with the observed data. We can see that most of the variables show acceptable results, with an average error of 10 percent. To judge these results one should keep in

21The reader will notice that this model does not include an explicit consumption function. There were two main reasons for this: a) the bad behavior of such an equation due mainly to statistical deficiences and b) stech an equation is estimated implicitly when we estimate domestic savings. 
mind that the forecast is done in first differences, so an error of estimation between actual and simulated values of 10 percent is equivalent in many variables to less than 1 percent in terms of their levels.

The model has three primary areas of difficulty. (1) One such problem appears in the GDP equation where the regression coefficients are not significant (" $t$ " statistics are very small) for the first differences of the Govemment expenditure variable. So the level of such expenditures was used to obtain a better result. This shortcoming means that the Keynesian "multiplier" is not a significant variable for explaining changes in total nominal expenditures. The significance of the dummy variable shows the need to try other explanatory variables in this equation, incorporating monetary actions in a more direct form than the one presented here in which interest rates enter only indirectly in the process of determining private investment. (2) The estimated financial equations are heavily dependent on interest rates, which are assumed exogenous and not significant for the changes in nominal GDP, contradicting the endogeneity expected in this model. (3) The model does not include a price equation because no satisfactory results were obtained, even though different approaches were tried. All the variables in this model are expressed in nominal terms, assuming that such variables have the same behavior in real terms, prices being relatively stable (which has been the experience in the sample period and was typical of most of the early versions of Keynesian models). ${ }^{22}$

In spite of these limitations, the model performs within a reasonable degree of confidence. An application of the model to a forecast for 1973 is presented in Table II.

\section{A Summary of the Monetany Model Structure}

The main exogenous variable in this model, in contrast to the fiscal model, is the money supply, which is defined as currency plus demand deposits held by the nonbank public. It follows the monetarist's view that the rate of monetary expansion is the main determinant of total spending, in this case measured as nominal gross domestic product.

Changes in total spending are reflected as movements in "real" output and prices (see Exhibit II). If

22In the monetary model a price equation was estimated, and its results are acceptable. This equation was found after numerous disappointing trials, but by that time the fiscal model had been completed. A future version of the fiscal model should include sach an equation.

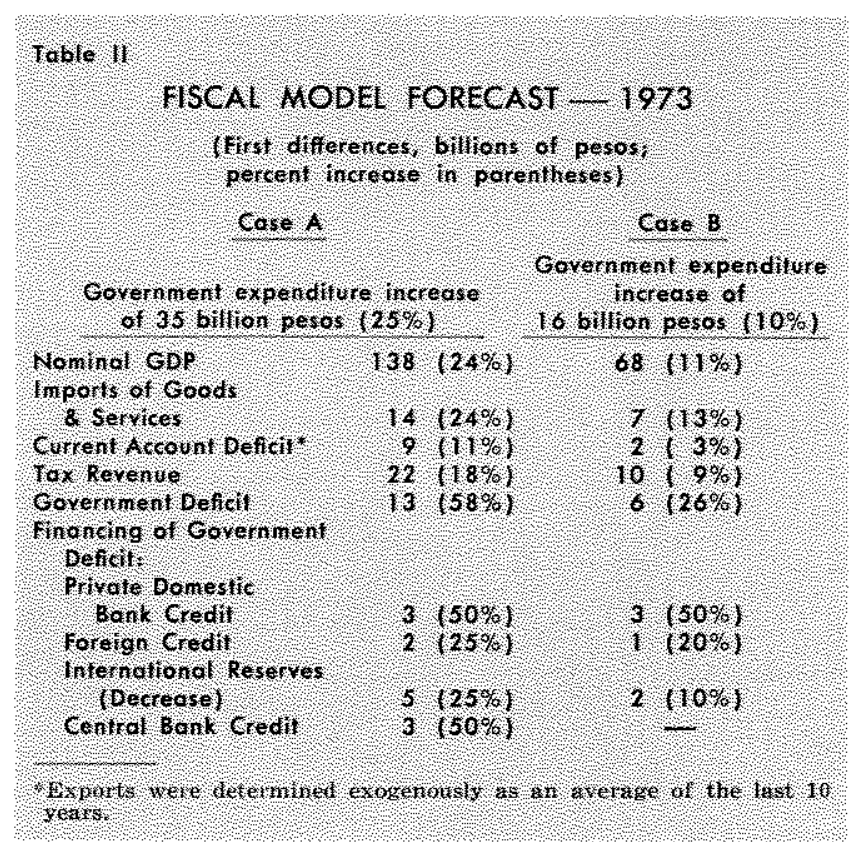

the rate of growth of nominal GDP is not accelerated greatly beyond its trend, prices will not be affected and increased real GDP growth will be possible as existing capacity will be used more efficiently.

Special consideration is given to the external sector due to its impact on the level of spending. An increase in imports over exports means that domestic demand for goods and services exceeded domestic supply and, therefore, part of the spending stream was directed to the "rest of the world." This would mean that the balance of payments in an open econony like Mexico plays an important role in total spending; but it also affects the changes in the stock of money. If there is a deficit in the balance of payments, international reserves will flow out of the country, producing a contraction in the monetary base and consequently in the money stock if not offset by other actions of the central bank or by a corresponding inflow of foreign debt.

Balance-of-payments deficits will be possible only if the stock of money exceeds the amount demanded. This excess supply will ultimately lead to higher prices of domestic goods and/or to additional purchases of foreign goods, services, and assets, with the consequent loss of reserves by the central bank. This loss of reserves, if not offset by the central bank in the next period, would result in a reduction of the money supply (or an equivalent inflow of foreign capital). Otherwise, the process of increased spending in domestic and foreign goods and services would go on. Since a deliberate policy has been followed in Mexico to acquire the foreign capital necessary for the develop- 


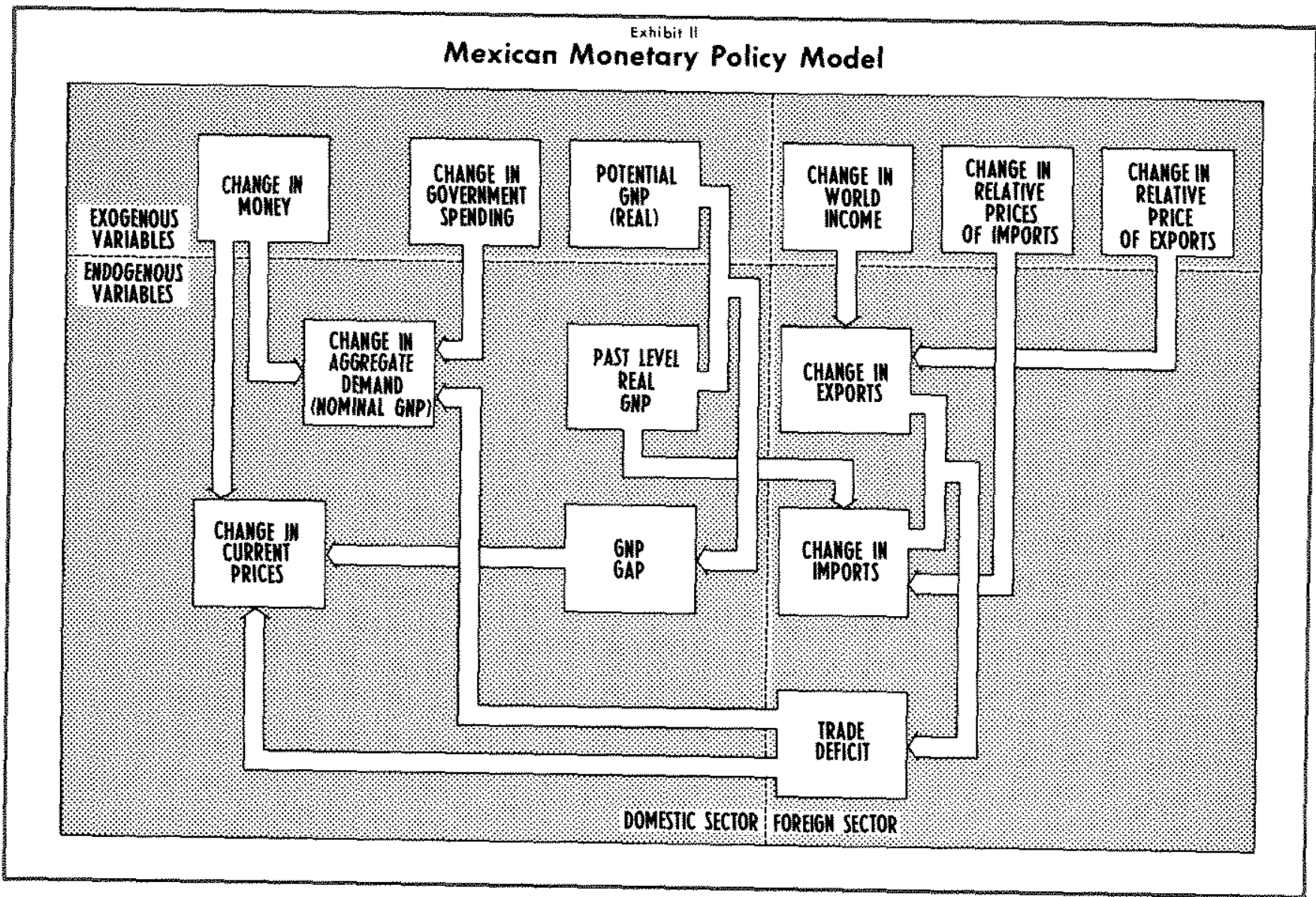

ment process, the deficit is considered endogenous in the model.

Imports and exports are endogenous variables, which, when netted, produce a balance-of-trade defioit, and act as an exogenous influence on spending in the following period. Therefore, only indirectly (by changes in real GNP) can a deficit in the balance of payments be affected by policymakers.

Fiscal actions are introduced in the model as Gov. ernment expenditures. ${ }^{23}$ However, if such Government expenditures are not financed by monetary expansion, but by taxes or private borrowing from the public, we would expect a "crowding out" of private expenditures to take place and this variable to have little effect on total spending.

This point is really the motivation for the econometric exercise presented here. The Mexican experience demonstrates that during the inflationary period when budget deficits were financed with "new" money,

23It was not possible to estimate the equivalent to a "high employment budget" which would have been a preferable variable in this equation. total expenditures were growing at rates faster than in the period of stability. But the increased expenditures of the first period were transferred in part to imports and to prices, because real output could not keep pace with nominal spending. Therefore, Government expenditures were behind the inflation and balance-of-payments deficit, even though it acted as a stimulus to the growth of real GDP.

In the recent period when budget deficits have been financed through the "crowding out" process, the fiscal deficit becomes ineffective on total spending because it only substitutes private outlays for Government outlays, and no considerable inflationary pressure is exerted on the economy. Therefore, the money supply becomes the key variable in short-term economic policy, a fact that probably has not yet been generally recognized in Mexico. This is probably because the central bank has followed a policy of sustaining a fixed rate of growth in the money stock while financing increased Govemment deficits with funds that would otherwise be directed to the private sector. The experience of 1971 makes this behavior clear. When money supply was not reduced as sharply as Govemment expenditures, pressure on prices did 


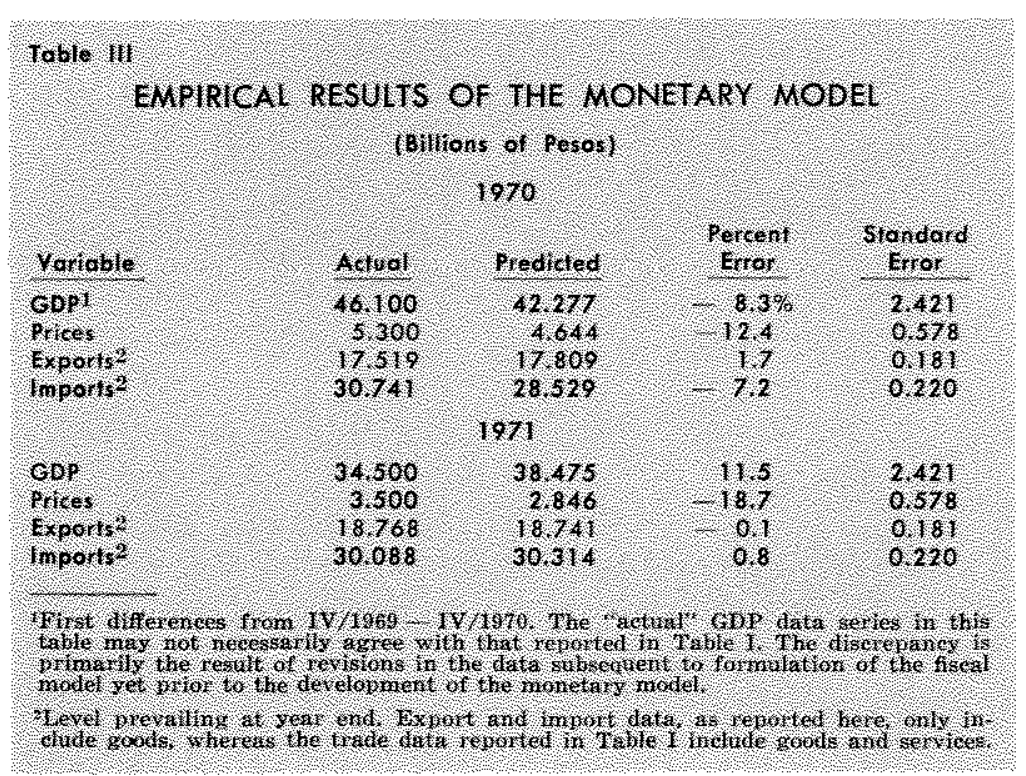

(2) As a consequence of (1) the "highemployment budget" concept could not be used in the total spending equation, which would have been more adequate than Government expenditures. The use of Government expenditures instead introduces different elements of variability such as seasonal, postponement, advances, etc.

The price equation, which was obtained after many unfruitful trials, shows a welldefined pattem with the gap between potential and actual GDP. When the gap is reduced, prices tend to rise in a Phillips curve fashion. Also changes in the rate of growth of the money stock will affect prices in a meaningful way. Net imports act in a reversed pattern; that is, increases in the balance-of-payments deficit will remove in-

not ease as much during 1971. However, the increased total spending together with increased monetary growth helped real output recover in 1972 and 1973.

\section{Empirical Results of the Monetary Model}

As was mentioned before, the estimation of this model was made with quarterly figures, which was possible given the availability of data in a small model ( 6 endogenous variables and 6 exogenous) like this. The simulation for 1970 and 1971 , presented in Table III, was on a quarterly basis, but aggregated annually to make it comparable with the results obtained from the fiscal model. These results are also generally acceptable with a 10 percent average deviation from observed figures in first difference. The results for 1971 are not as good as those for 1970 , but considering how atypical that year was in the sample period, the results are quite encouraging. It should also be noticed how much the simulation for nominal GDP improves in this model, with much fewer exogenous variables than the fiscal.

There are two shortcomings in this model. (1) Since there are no figures on unemployment in Mexico, the assumption was made that the economy will always be well below full employment with respect to the total labor force. But considering only the "skilled" labor force we could very well conclude that the Mexican economy often has reached "full employment." Therefore, the estimation of the gap between potential GDP and actual GDP was made on a totally arbitrary basis. Potential real GDP was measured as the average standard deviation from the maximum rate of growth of real GDP in the sample period. flationary pressures from the Mexican economy.

Probably the most encouraging result of the model is the total spending equation, which is one of the best of all the equations estimated for the two models. This equation has the advantage that it is potentially consistent with both Keynesian and quantity theory models. The results show that only changes in money significantly affect total spending. Government expenditures and the balance-of-payments deficit help in explaining such spending, but the regression coefficients are not significant.

The influence of monetary actions, besides being large, is also rapid as a three-quarter lag was found significant. The correlation was reduced when this lag was increased to 9 quarters. ${ }^{24}$

It seems that even though the Government is "totally free" to determine its level of expenditures, it only decides which sector will account for the increase in total spending. If the central bank does not offset the "normal" rate of growth of the money supply, given an increased Government deficit, total spending will continue at its pace - assuming that no structural changes attributable to the development process take place. ${ }^{25}$

\footnotetext{
H4t is sarprising how this equation followed the results obtained by Andersen and Jordan for the U.S. economy, but the nature of the method followed to finance Government deficits since 1959 in Mexico makes the results more "logical."

25 Stuctural changes refer to changes in capital formation, production, natural resources, population, efe.
} 
The models help us conclude that in the development process of Mexico the increasing role of the fisoal sector in economic policy proved healthy in early stages, making the economy better off than if the Government had not acted. This was particularly true in the early stages of Mexican economic development when the Keynesian multipliers acted fully. What remains to be seen is whether the multipliers will continue to operate in the future as they have in the past; with this knowledge we will be able to determine the suitability of existing economic policy to handle new goals. Of course, this will infuence greatly the conclusions we draw about the effects of the Government sector's spending productivity compared to that of the private sector's, especially at a time in which more social type spending is necessary and the stage of heavy infrastructure investment is almost completed.

The questions that the policymakers will have to answer can be summarized as follows. Should economic policy forget about financing the budget in a non-inflationary way with the risk of reducing the rate of spending and eventually that of real economic growth in the future? Should the Government go back to financing this deficit with "new" money and increase spending in an inflationary way? Or should the Government enter the capital market and compete for funds, thus paying higher rates on its debt than those now paid to the private banks? The answers to these questions will have to be based on the long-term goals of economic policy, which in turn will have to be implemented in the short term. With the structure developed here the costs of alternative shortterm actions can be approximated.

The 1973 forecast of this model (Table IV) as well as that presented for the fiscal model can give an idea of what large Government deficits financed with new money could do to the Mexican economy and also how a very restrictive monetary policy depresses the economy considerably.

\section{CONCLUSIONS}

The purpose of this paper has been to develop two short-term econometric models of the Mexican economy based on the empirical evidence of the last 15 years. Recent theoretical and statistical developments in the field of short-term economic policy in industrialized countries are applied and evaluated. The models are framed around the two primary theoretical approaches to income-expenditure determination the fiscal and monetary approaches.

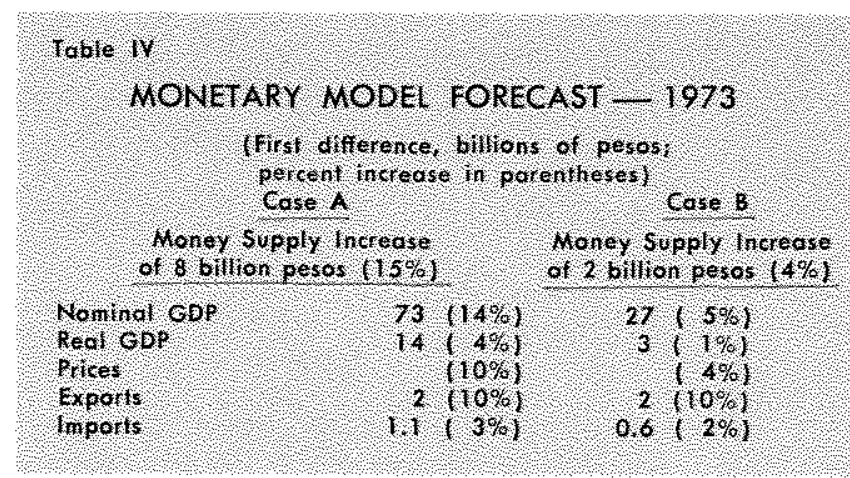

In the fiscal model the hypothesis tested is that Government expenditures, which are exogenous, have wide and fast effects on economic activity. In the monetary model the stock of money is the exogenous variable assumed to have such effects on economic activity.

The particular way in which the Mexican economy has evolved in the last 15 years made the experiment feasible. The conditions of continuous growth in real GDP with price stability, free convertibility of the peso, and a rapidly growing financial sector are rare in developing countries. The absence of such conditions would have introduced severe restrictions in the models.

Both models utilize data from the 1960-1971 period. Even though the fiscal model uses annual data and the monetary model uses quarterly data, the simulation and forecasting results were not substantially different. In spite of great data limitations, both models perform well in general terms and there seems to be no considerable contradiction between them. In fact, both models supplement each other well and facilitate the analysis of Mexican economic policy.

The following conclusions can be drawn from this exercise.

(1) Government expenditures, although an important policy variable, do not affect the level of total spending (GDP); they primarily act as a substitute for the private expenditure that would have taken place otherwise, through the "crowding out" process.

(2) As mentioned earlier, Government deficits are financed to a great extent by the private banks, buying Treasury bills to cover reserve requirements, and therefore leaving less credit available to the private sector. Increased taxation has not been used widely as an offset since it is argued that taxes have large and potentially perverse allocation effects in the development process. As a result, the central bank 
has seldom expanded the money supply beyond trend rates to finance Government deficits. Money supply has been increased at a rate consistent with the growth of real GDP, thus resulting in a "tolerable" rate of inflation ( 3 percent).

(3) The money stock, with its large and fast (3 quarters) influence on total spending, is a very important variable in short-term economic policy.

(4) At high levels of employment (small GDP gap), increased spending will be reflected rapidly in higher domestic prices and increased imports. Therefore, Mexican economic policy faces a trade-off between growth and price stability. If one of the two goals is pursued actively, the other will not be achieved. This trade-off is similar to that implied by the Phillip's curve.

(5) The balance-of-payments deficit is a built-in constraint to short-term economic policy because imports respond with an elasticity greater than unity to changes in the rate of growth of real GDP. The growth process requires increasing amounts of imports, mainly of capital goods. Also, imports of consumer goods respond to increased income, while exports depend on world demand and relative prices for Mexican products vis-á-vis the rest of the world.

(6) Large and abrupt changes in policy variables affeot investment, imports, and prices. If real growth is promoted at very high annual rates ( $7 \%$ or more), pressures develop on prices and on the balance of payments. If the inflation and loss of international reserves accompanying this procedure are extended for a long period of time, it will eventually be judged as an excessive pressure and a contraction in the policy variables will be recommended. This action will slow economic activity and, again, if extended for some period of time, will become "too contractionary" and another swing in policy will be called for. This process, when carried out for a period of time, will produce uncertainty and imbalance in the forces involved in the economic process.

Based on these conclusions, the following shortterm economic policy guidelines are recommended.

(1) Sharp changes in Government expenditures should be avoided and a stable rate of growth sustained so that real GDP will increase at about 6 or 6.5 percent - a rate which, historically, is not associated with excessive price pressure.

(2) Sharp ohanges in the growth of the money stock should be avoided. Even if recommendation (1) is not met, this would be possible as long as the past procedure for financing Government expenditures is continued in the future, or Government expenditure increases are offset by increases in taxes. If recommendations (1) and (2) are met, prices will increase at a moderate rate. Net imports and private investment will also respond in a desired fashion.

(3) Once the economy is put on the "right track" the structural problems of employment and income distribution can be attacked. This will undoubtedly require additional Government expenditures which, if financed by the "crowding out" process, will affect private investment, and consequently real growth. Even if the alternative of less real growth would be better income distribution, the Mexican economy may have a net gain in the long run and an increase in potential future growth.

The goal of better income distribution requires additional study of the industrialization process, the educational system, the "dual" agricultural system, and regional development, to mention just a few of the areas. It should be clear that any structural changes can take place only if the short-term goals of the economy are achieved. In addition, long-term policy targets must be realized in accordance with the available policy instruments if the prevailing economic system is to remain in operation.

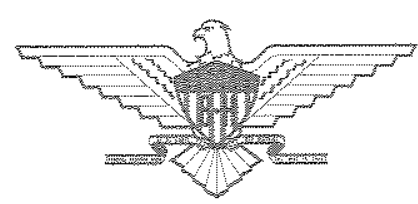

